Afr. J. Trad. CAM (2005) 2 (3): 274 - 281

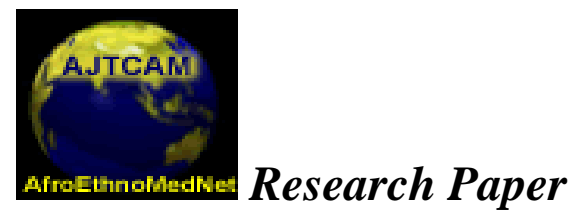

Afr. J. Traditional,

Complementary and

Alternative Medicines

www.africanethnomedicines.net

\title{
ISSN 0189-6016@2005
}

\section{TOXICITY POTENTIALS OF SENNA PODOCARPA (GUILL.ET PERR.) LOCK PODS IN RODENTS}

\author{
M. A. Akanmu' ${ }^{1}$, E. O. Iwalewa ${ }^{1}$, A. A. Elujoba ${ }^{2}$ and K. A. Adelusola ${ }^{3}$ \\ ${ }^{1}$ Department of Pharmacology and ${ }^{2}$ Department of Pharmacognosy, Faculty of \\ Pharmacy, and ${ }^{3}$ Department of Forensic Medicine \& Morbid Anatomy, College of \\ Health Sciences, Obafemi Awolowo University, Ile-Ife, Nigeria \\ Email: maoakanmu@yahoo.com, Tel: +234-8035958466
}

\begin{abstract}
The effects of acute $\left(\mathrm{LD}_{50}\right)$ and sub-chronic doses of the aqueous infusion of Senna podocarpa (Guill. et Perr.) Lock pod on the liver, kidney, brain and testis of mice and rats were studied, respectively. The acute toxicity studies did not produce any observable lethal effects and the calculated $L_{50}$ was $6.6 \mathrm{~g} / \mathrm{kg}$. The histopathological analysis of the liver, kidney, brain and testis showed no adverse effect. Behavioral observations and the histopathological findings did not show significant differences between the control and the treated groups. There were no marked adverse alterations or degeneration of tissues since these vital organs showed normal architectures suggesting no morphological disturbances as compared with the control group. The findings indicated that the aqueous infusion of $S$. podocarpa pod was devoid of overt acute and sub-chronic toxic effects in mice and rats.
\end{abstract}

Key words: Senna podocarpa pods; acute toxicity, sub-chronic toxicity.

\section{Introduction}

Senna podocarpa (Guill. et Perr.) Lock formerly Cassia podocarpa Guill. et Perr. (Leguminosae-Caesalpinioideae) is a glabrous shrub up to $5 \mathrm{~m}$ high. It is widely distributed in West Africa and could be found in the Savanna forest area of the region. The plant is locally found on old farmlands in both western and northern parts of Nigeria (Riley, 1963; Dalziel and Hutchinson, 1958). This plant has been used extensively in the folklore medicines for the treatment of a variety of diseases in especially among the Igbo and Yoruba speaking tribes of Nigeria where it is known locally as Agelo-ogala and Asuwon, respectively (Adefemi et al., 1988). The ripe fruits are brownish-black, shiny, flat-beaked, slightly curved with small transverse ridges, indehiscent, $10-12 \mathrm{~cm}$ long and $1.5 \mathrm{~cm}$ broad. In Nigeria, Senna alata (Linn.) Roxb. formerly Cassia alata Linn and Senna podocarpa are used in traditional 
medicine for the treatment of skin diseases such as eczema, scabies and ringworm (Sofowora, 1986). S. podocarpa leaves are extensively used for their antigonorrhoeal and purgative properties as well as a guinea-worm and sore-healing remedy among the Igbos (Akanmu, 1999; Elujoba et al., 1994; WHO, 1999). The decoction of the leaves, roots, and flowers is given for the treatment of veneral diseases in women (Wallis, 1967). The leaf infusion or decoction is also given as a mild laxative and in large doses it acts as a purgative (Trease and Evans, 1996). Like many other members of the genus $S$. podocarpa contains anthraquinone derivatives, responsible for the laxative properties (Dalziel, 1937; Elujoba et al., 1989). Extracts obtained from species of Senna have been scientifically described as anti-fungal (Kasuko and Nagayo, 1951), anti-viral (Barbber and Rani, et al., 1981) and anti-cancer (Buttiner et al., 1973). Constituents of the leaves and pods of $S$. podocarpa that have been identified include rhein, emodin, chrysophanol and other combined and free anthraquinones (Rai and Obayemi 1973; Rai and Abdulahi, 1978; Elujoba et al., 1994). Previous study by Adefemi et al., 1988 on the toxicity potential of the leaves of this plant showed that repeated administration of different doses caused tissue degenerative changes in the liver and kidneys of rats. The present effort is aimed at investigating the toxicity potential of the pods of $S$. podocarpa on selected organs of rodents.

\section{Materials and Methods Plant Material}

The pods of Senna podocarpa (Guill. et Perr.) Lock, formerly Cassia podocarpa Guill. Et Perr. (Leguminosae-Caesalpinioideae) were collected from locations at Ile-Ife in Osun State, Nigeria in the month of May. The identification of this plant was carried out by comparison with the established Herbarium specimen with Voucher Number FHI 57961 in the Forest Research Institute of Nigeria (FRIN), Ibadan, Nigeria, following authentication by Mr. Adesakin, the plant curator in the Department of Pharmacognosy, Faculty of Pharmacy, Obafemi Awolowo University, Ile-Ife, Osun-State of Nigeria.The pods were dried and then comminuted using a grinding machine (Machine Type B” Lab mill, Chelmsford, England). The sample was stored in amber colored bottle and kept in a dry cupboard until ready for use.

\section{Preparation of Infusion}

$5 \mathrm{~g}$ of dried powdered pods of Senna podocarpa was placed in a conical flask unto which $50 \mathrm{ml}$ boiling was added to give $100 \mathrm{mg} / \mathrm{ml}$ concentration and to infuse for 20 minutes before being filtered (Elujoba and Iweibo, 1988; Sofowora, 1993).

\section{Animals}

Swiss albino mice (18-20 g) and Wister rats (180-240 g) were obtained from the Animal House of Pharmacology Department, Faculty of Pharmacy, Obafemi Awolowo University, Ile-Ife and Department of Pharmacology \& Therapeutics, University of Ibadan, Ibadan, Nigeria, respectively. All the animals were kept under standardized environmental conditions and had free access to food and water. All experimental procedures followed animal research guidelines. 


\section{Acute toxicity study}

Swiss albino mice weighing between $18-20 \mathrm{~g}$ were used and they were randomly allocated to five groups $(n=20)$ testing conditions and each mouse was used only once. Each group of mice was placed in the test cage for a 30-minute habituation period before any oral administration of the drug. The mice were weighed and were fed orally with the appropriate pod infusion extract or the control solution (distilled water), using an oral syringe and immediately returned to the cage for observation. The $\mathrm{LD}_{50}$ was determined by oral route according to the method of Karber adapted by Aliu and Nwude (1982).

\section{Sub-Chronic Toxicity Studies}

Sixteen male Wister rats (180-240g) were randomly distributed into four groups. The first group (Group I) served as the control and received distilled water. Groups II, III and IV received S. podocarpa infusion at doses of 250, 500 and 1000 $\mathrm{mg} / \mathrm{kg}$ per os respectively. Rats in the control group received distilled water in equivalent volumes as those in the $1000 \mathrm{mg} / \mathrm{kg}$ groups. The doses for $S$. podocarpa were selected after preliminary pilot screening that showed that the infusion of the pod possessed very low acute oral toxicity. The animals used in this study received their respective doses once a week for six weeks and had free access to food and water. They were observed daily for physical and behavioural signs of toxicity or any pharmacological reactions. At the end of six weeks, the rats were sacrificed by decapitation and the vital organs namely the liver, kidney, testis and brain of each rat were carefully removed and observed grossly. Portions of the organs were fixed in $10 \%$ formal saline for further histopathological investigations.

\section{Results}

In the acute toxicity study, the aqueous pod infusion of Senna podocarpa did not produce any mortality up to the oral dose level of $16 \mathrm{~g} / \mathrm{kg}$ body weight in mice. There were no significant changes in the behavior in relation to the posture, mood and motor activity. The results of the histopathological examination are reported based on the doses of the infusion administered under the sub-chronic experiments (Figures 1$3)$.

General histopathological analysis of the liver in the control group showed only congestion of the central vein, while the sinusoids and the portal areas were found to be essentially normal (Figure 1a). In the testis, the cells of the spermatogenetic lineage were normal while the seminiferous tubules were well preserved with orderly maturation of cells of the spermatogenetic lineage; there was no inflammation in the interstitium (Figure 2a). The tubules in most parts of the kidney cells were normal (Figure 3a) and there was no damage to any brain cell or structure. The results obtained also showed that the sub-chronic administration of different doses of $S$. podocarpa pod infusion did not produce any adverse effects on the liver. The portal tracts were observed to be normal and the central vein only showed mild congestion at $250 \mathrm{mg} / \mathrm{kg}$. 
Afr. J. Trad. CAM (2005) 2 (3): 274 - 281

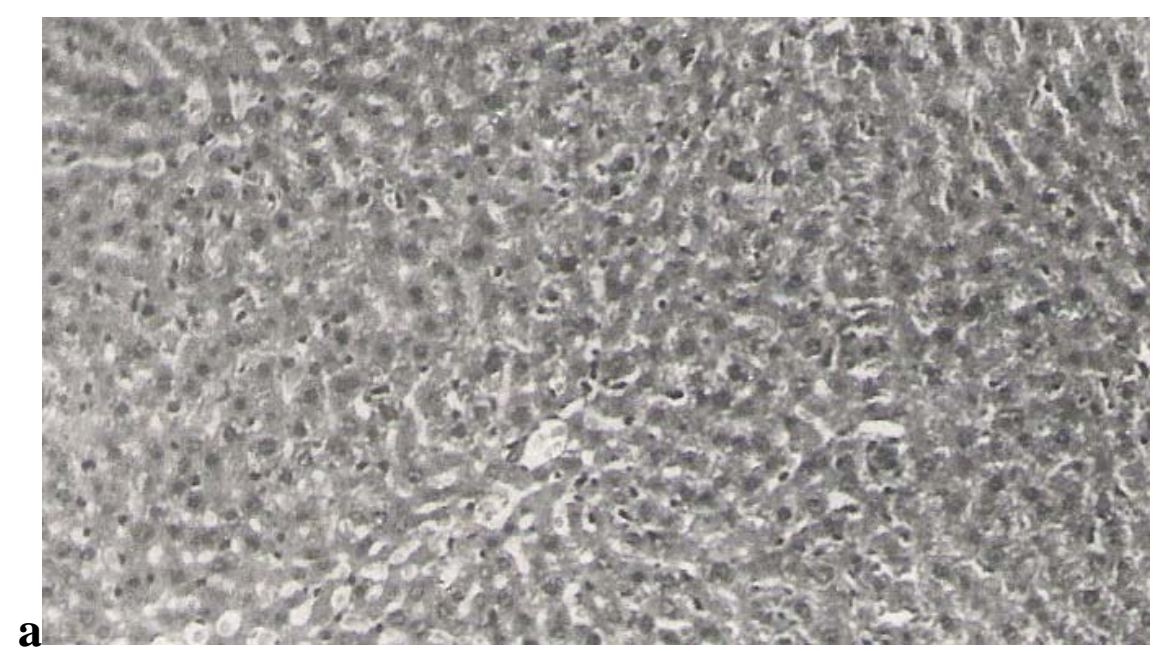

$\mathrm{H}$ and $\mathrm{E}$ X160

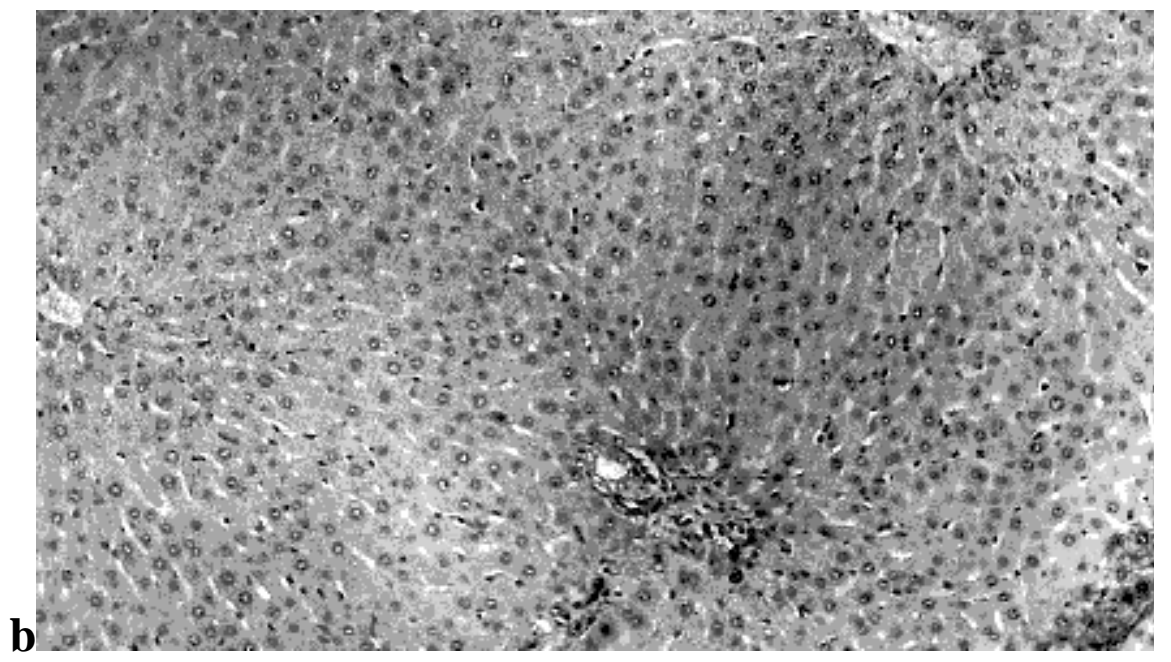

$\mathrm{H}$ and $\mathrm{E}$ X 148

Figure 1: Photomicrographs of a section of liver of the control rat (Figure 1a) or rat treated with repeated administration of the aqueous infusion of Senna podocarpa pods at a dose of $1000 \mathrm{mg} / \mathrm{kg}$ showing that the cells generally maintained normal architecture (Figure 1b).

With the administration of $500 \mathrm{mg} / \mathrm{kg}$, however, the sinusoids and central veins were congested but the portal tracts were not widened and the limiting plates were respected. Similar observations were seen with the administration of the highest dose $1000 \mathrm{mg} / \mathrm{kg}$ with the central veins being prominent and the cells generally maintaining normal architecture (Figure 1b). The testis showed well-preserved seminiferous tubules with complete normal cells of the spermatogenetic lineage at $1000 \mathrm{mg} / \mathrm{kg}$ and the interstitium showed no inflammation or fibrosis and the overall picture was essentially normal for all other doses studied. Figure $2 b$ showed the photomicrograph of testis of rat given an oral dose of $1000 \mathrm{mg} / \mathrm{kg}$. In the kidney, it was observed that the glomerular tufts, the blood vessels and the interstitium were quite normal. There was no degeneration of tissues and the tubules (mainly proximal convoluted tubules) showed minor focal necrosis of the epithelium in the $1000 \mathrm{mg} / \mathrm{kg}$ group. However, the blood vessels and the interstitium were essentially normal 
(Figure 3b). The brain was generally observed to be normal with no damage to any brain structure.

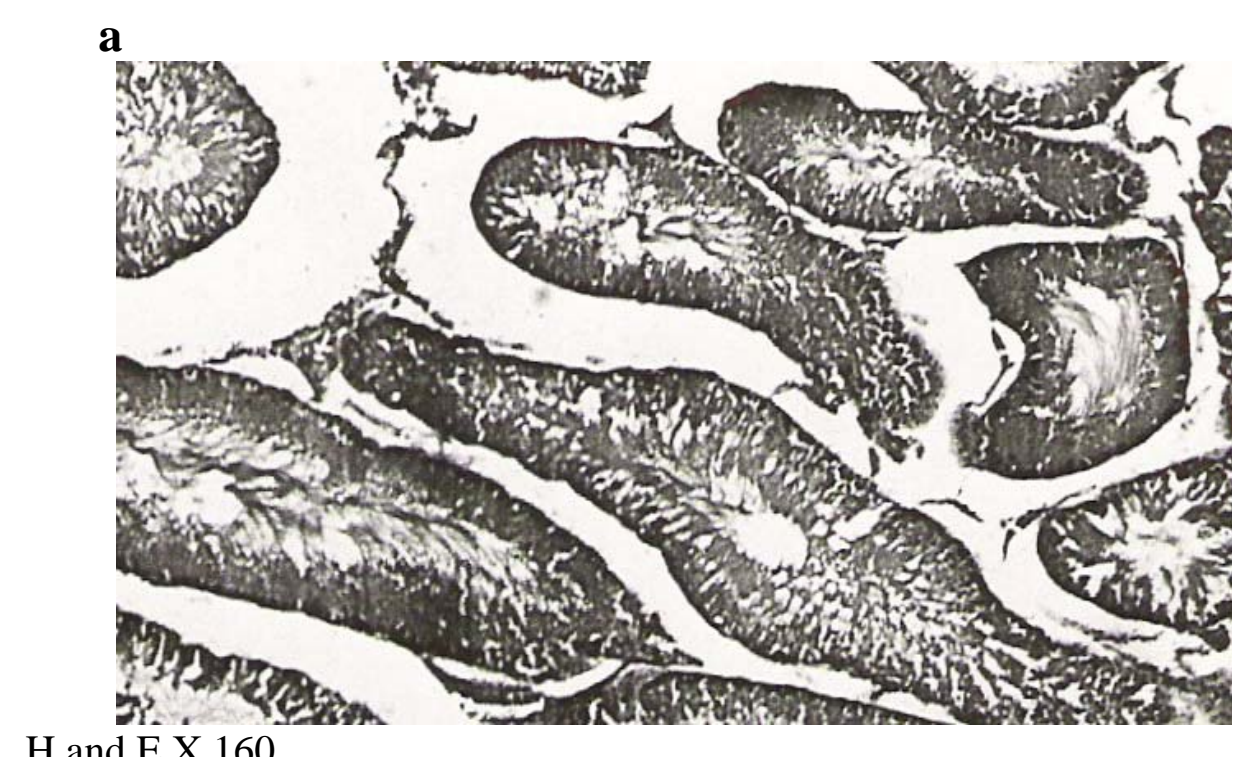

$\mathrm{H}$ and $\mathrm{E} \mathrm{X} 160$

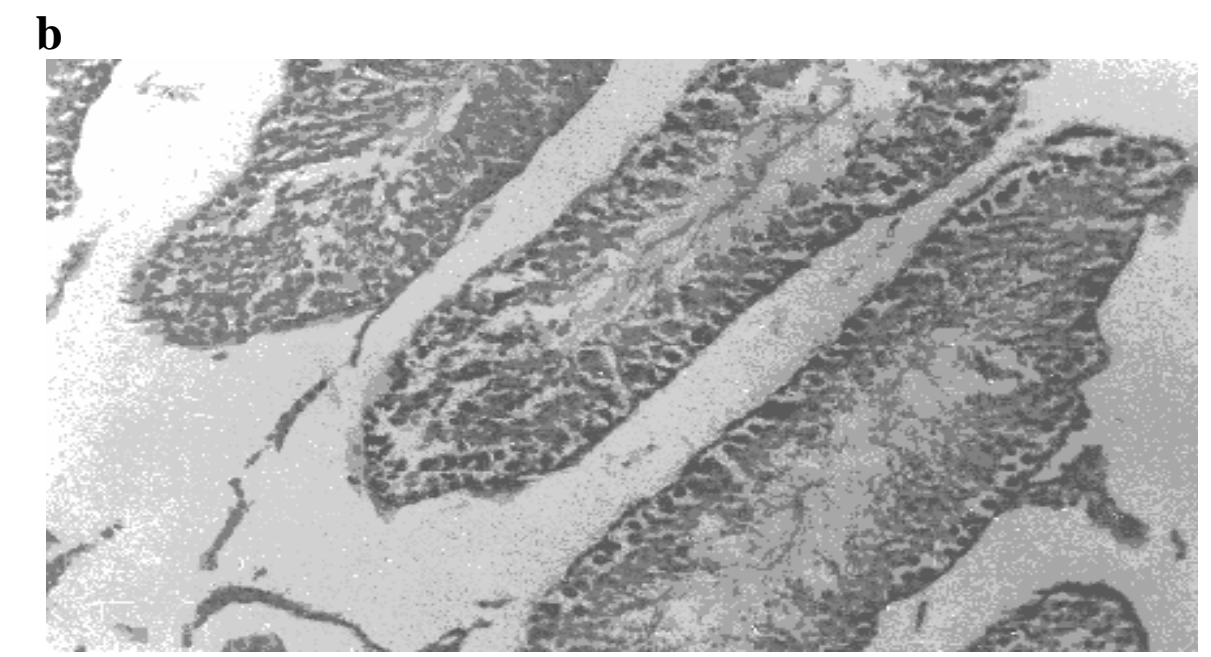

$\mathrm{H}$ and E X 320

Figure 2: Photomicrographs of a section of testis of the control rat (Figure 2a) or rat treated with repeated administration of the aqueous infusion of Senna podocarpa pods at a dose of $1000 \mathrm{mg} / \mathrm{kg}$ showing that the interstitium was normal and no inflammation or fibrosis (Figure 2b).

\section{Discussion}

The genus Senna consists of anthraquinone-containing plants, which have been extensively used for medicinal purposes in folkloric medicine. Besides, constipation, some have been used for the treatment of various other ailments including gonorrhea, leprosy, worms, diarrhoea, diabetes, skin eruptions, eczema, and constipation (Sofowora, 1986; Wallis, 1967). 


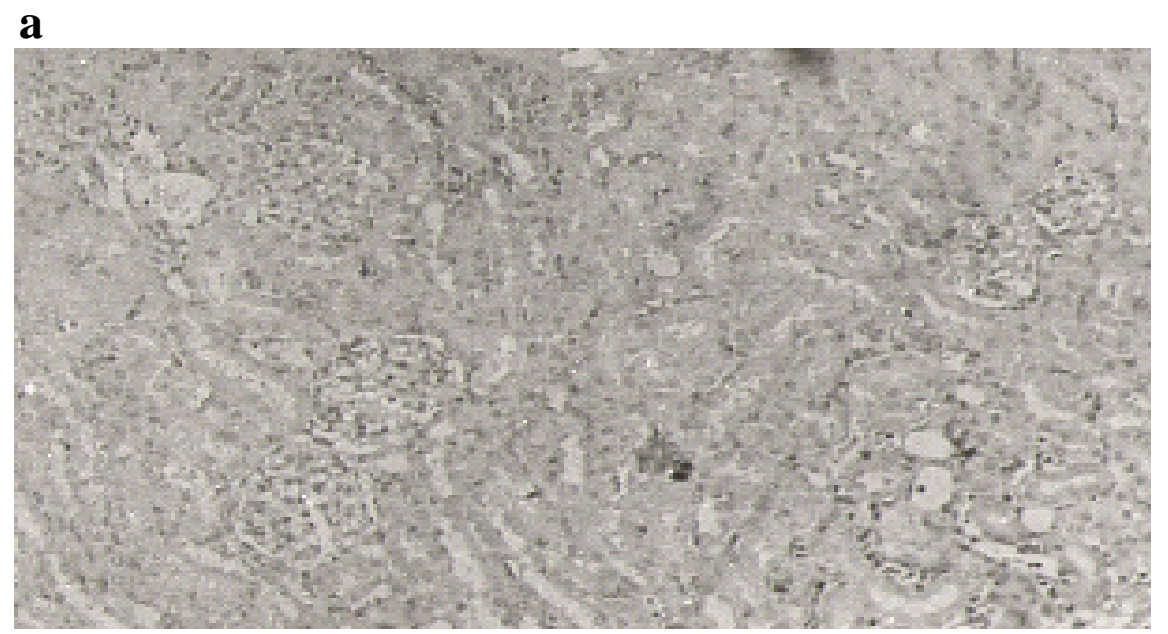

$\mathrm{H}$ and $\mathrm{E} \mathrm{X} 148$

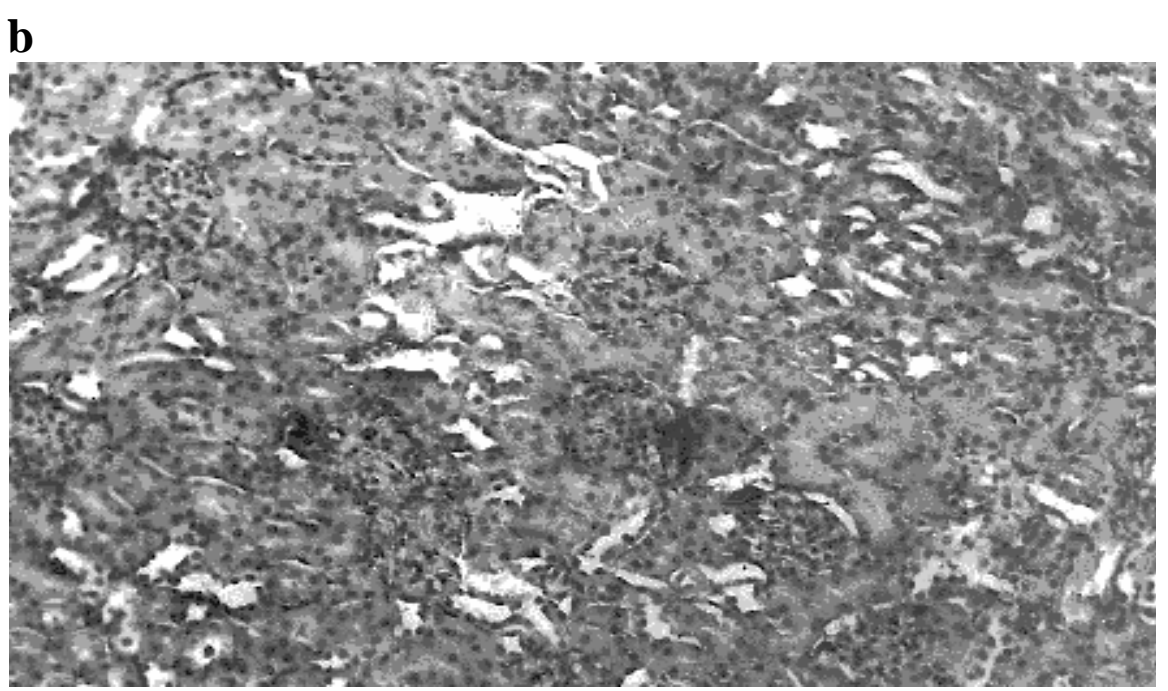

$\mathrm{H}$ and $\mathrm{E} \mathrm{X} 160$

Figure 3: Photomicrographs of a section of kidney of the control rat (Figure 3a) or rat treated with repeated administration of the aqueous infusion of Senna podocarpa pods at a dose of $1000 \mathrm{mg} / \mathrm{kg}$ showing minor focal necrosis of the epithelium of the proximal tubules (Figure 3b).

The laxative and purgative activities are the famous biological properties (Elujoba et al., 1993, Elujoba et al., 1988; Sofowora, 1986; Wallis, 1967). The crude extracts of Senna podocarpa leaves have been reported to possess laxative properties (Akanmu, 1999; Elujoba et al., 1989; Elujoba et. al., 1994). The present study was undertaken in order to evaluate the toxicity potentials of the aqueous infusion of the pod of this plant and from the results obtained, the aqueous pod infusion was observed not to induce any acute toxic effect of mortality up to the dose level of 16 $\mathrm{g} / \mathrm{kg}$ body weight in mice. Under the sub-chronic dose experiment, the aqueous $S$. podocarpa pod infusion at 250, 500, and $1000 \mathrm{mg} / \mathrm{kg}$ (p.o.), did not produce any changes in the rat's behavior, food and water in-take. Also, when compared to the 
control group, the pod infusion at doses of 250, 500, $1000 \mathrm{mg} / \mathrm{kg}$ did not produce any potential toxicity on the liver since there was no necrosis, inflammation or fibrosis (Figure 1b). The limiting plate was found to be well preserved and the central veins were normal. The testis showed well preserved seminiferous tubules with evidence of complete spermatogenesis and there was no interstitial fibrosis or inflammation (Figure 2b). The brain was normal with no evidence of degeneration of brain cells. The kidney section showed preserved renal tubules and the interstitium was well preserved. There was no inflammation or fibrosis and the blood vessels remained essentially normal. However, there was minor focal necrosis of the epithelium of the proximal tubules with the administration of the highest dose of $1000 \mathrm{mg} / \mathrm{kg}$ (Figure 3). The histopathological examinations of these vital organs such as the liver and testis, following repeated oral administration of $S$. podocarpa pod infusion, showed normal architectures suggesting no morphological disturbances. These findings indicate that the aqueous pod infusion of $S$. podocarpa possessed low level of toxicity and may be relatively safe as laxative drugs for human use than the leaf extracts. It had been earlier reported by Adefemi et al., (1988) that the leaf extracts caused a widespread degenerative change in the kidney tubules, tubular necrosis and tubular regeneration.

In conclusion, this study showed that acute administration of $S$. podocarpa pod infusion is relatively safe. However, the repeated administration revealed its possible toxicity on the kidney at high dose. Thus, there is need for caution in using the pod infusion for a long period.

\section{Acknowledgement}

We acknowledge Obafemi Awolowo University, Ile-Ife for staff development program for Akanmu M. A. and Scientific, Technical and Research Commission of the Organization of African Unity (OAU/STRC) Lagos for African Pharmacopoeia efforts.

\section{References}

1. Adefemi, O.A., Elujoba, A.A. and Odesanmi, W.O. (1988). Evaluation of the toxicity potential of Cassia podocarpa with reference to official senna. West Afri. J. Pharmacol. Drug Res. 8: 41-48.

2. Akanmu, M.A. (1999). Evaluation of the toxicity potential of Cassia podocarpaand Cassia fistula fruits. M.Sc. Thesis Obafemi Awolowo University, Ile-Ife, Nigeria. p19-20.

3. Aliu, Y.O. and Nwude, N. (1982). Veterinary Pharmacology and Toxicology Experiments. $1^{\text {st }}$ Edition ABU Press. p104-110.

4. Barbber, O.P. and Rani, A. (1981). Studies on the possibilities to infect the cells of callus of $C$. fistula by an animal virus to induce production of interferon. Indian J. Exptl. Biol. 19:348-355.

5. Bordoloi, D., Baruah, J. N., Gangaly, D. and Rao, P.R. (1964). Effect of polyphenolic extracts of $C$. fistula and Acacia catechu on the spore germination of Colletorichum falcatum. Current Science 33:408.

6. Buttiner, M., Bhakhuni, D.S. and Silva, M.E., (1973). Anticancer agents from Chilean plants Cassia obtuse. Rev. Latinaemor, Quim, 4: 8-12, through CA 79.12360U. 
7. Dalziel, J.M. (1937). The useful plants of West tropical Africa, Crown agents for the colonies, London, p612.

8. Dalziel, J.M. and Hutchinson, J.D. (1958).Flora of West Tropical Africa, London, Vol. 1 part 2, p450-5.

9. Elujoba, A.A. and Iweibo G.O. (1988).Cassia podocarpa as substitute for official senna. Planta Medica 54: 372.

10. Elujoba, A.A., Ajulo O.O. and Iweibo G.O. (1989). Chemical and Biological analysis of Nigeria Cassia species for laxative activity. J. Pharm. Biomedical Analysis 12:1453-1457.

11. Elujoba, A.A. and Ogunti, E.O. (1993). Laxative activity of Cassia alata. Fitoterapia 5: 437-439.

12. Elujoba, A.A., Ogunti, E.O., Soremekun, R.D. and Iranloye, T.A. (1994). The Pharmacognosy and Dosage formulation of Cassia podocarpa leaf with reference to Senna. J. Pharm. Sci. \& Pharm. Pract. 2: 14-18.

13. Hodgson, E. and Levi, P. E. (1987). A Textbook of Modern Toxicology. New York. Elsevier Science Publishing Co. p233-285.

14. Fairbairn, J.W. (1965). Chemical Structure, mode of action and therapeutic activity of anthraquinone glycosides, Pharm. Weed. 100:1493-1499.

15. Kasuko, I., Nagayo, O. (1951). Effects of vegetable drugs on pathogenic fungi I.Effect of anthraquinone-glycoside containing crude drugs upon the growth of pathogenic fungi. Bull Pharm Research Inst. Japan 2:23-29.

16. Lock, J.M. (1988). Cassia Sens. Lat. (Leguminosae-Caesalpinioideae) in Africa. Kew Bull. 43:333-342.

17. Rai, P.P. and Abdulahi, N.I. (1978). Occurrences of anthraquinones in the leaves of Cassia species. Nig. J. Pharm. 9:160-165.

18. Rai, P.P. and Obayemi, O.M. (1973). Anthraquinones from the leaves of Cassia podocarpa. Current Science. 47:457-460.

19. Riley, H.P. (1963). Families of flowering plants of Southern Africa. University of Kentucky press. p22-30.

20. Sofowora, A. (1986). The State of Medicinal Plants Research in Nigeria. University Press, Ibadan, Nigeria. p86.

21. Sofowora, A. (1993). Medicinal Plants and Traditional Medicine in Africa, $2^{\text {nd }}$ Edition, Spectrum Books, Ibadan, Nigeria. p7.

22. Trease, G.E. and Evans, W.C. (1996). Pharmarcognosy $15^{\text {th }}$ Edition, London, J \& A Churchhill Ltd., p234-492.

23. Wallis, T.E. (1967). Text Book of Pharmacognosy $5^{\text {th }}$ Edition, London. J and A Churchhill Ltd. p81-82, 135.

24. World Health Organization (1999). WHO monographs on selected medicinal plants.Vol 1, WHO Geneva. p1-8. 